\title{
ENHANCE OUTPUT OF NATIONAL POLICIES THROUGH RECRUITMEN, SELECTION, AND COMPETENCE TO CHANGE OF NATIONAL CONDITION
}

\author{
Wiranto \\ Graduate School, Universitas Negeri Jakarta \\ wiranto412@yahoo.com
}

\begin{abstract}
This study explores the effects of recruitment, selection, competence and national policies to the changing conditions in Indonesia. 530 respondents from 25 provinces or 50 regencies/ cities across Indonesia participated in questionnaire pools in the study. Data were processed using path analysis technique. Results reveal that the recruitment process by political parties, the selection process by the Election Commission, and the competence of the leader, have positive correlations to the policies and the outcomes. The study highlights that without any improvements in the recruitment, selection, competency of leaders, and policies, no changes could be made by the leaders. It implies that a redefinition and actualization of recruitment, selection, competence, and policies should be made to ensure the changes to take place.
\end{abstract}

Keywords: change of national condition, actualization of recruitment, competencies, national policies.

Indonesia has benefitted for its natural resources and people. Natural resources like the mining the forest, and the other resources spreading over the country have qualified Indonesia as one of the riches country in the world. In addition, Indonesia also benefits for its manpower marked by its position as the four-ranked biggest population in the world with $67 \%$ of productive age. Those aspects refer to tangible asset the world has acknowledged as a potential to be a leading country with bright future. BBVA Research (2012) on a group of EAGLE (Emerging and GrowthLeading Economies) has placed Indonesia as one country to lead over China, Brazil, Korea, Russia, Mexico, Egypt, Taiwan, and Turkey. It is even incredibly predicted that Indonesia will have belonged to a group of country that is able to contribute $51 \%$ of its potential to the global development compared to that of G7 countries with $14 \%$.

Should Indonesia seriously utilize its potentiality to make a change and carry out sustainable growth, prediction and opportunity may widely open (Beer in Kahar, 2002: 452); (Potts \& Lamars in Purhantara, 2004: 36). Unfortunately, it does not apply to Indonesia which appears to be one country that takes longer time for a change, incredibly goes into large debt and bears a predicate as a failed State, the 63rd-Failed State, which was not far better than previous year of the 73rd, or equal to the 4th lowest category.Indonesia inevitably has low competitiveness as shown on 2011 Indonesia's Development Index (IDI) of 0.617. With this reference, Indonesia ranks the 124th out of 187 countries (Aulia, 2013). The black and white numbers referring to economic growth and seeming to bring hope might not necessarily indicate people's welfare and independence in economic sector. Indeed, there has been a major gap in economic inequality and the high rates of poverty and unemployment. 
Welcoming the General Election, currently, there have been a number of slogans the future leaders of executives and legislatives voice to promote a commitment to a change as part of their political campaign. To make a change, they have to set out a public policy accordingly. The policy does not only emerge from the central or local government obliged to carry out public mandate but also is adopted from public opinion and oriented to public interest. The output of the policy should bring impact to half or the whole people of the country either in direct or indirect manner.

Thus, an appropriate policy is required to promote a change leading this country off status quo which relies solely upon a tangible asset. Indonesia definitely has to also explore the intangible asset heading to a new Indonesia to promote truth and equality for a brighter future.

With a view to making a change for the better future, it is recommended that an appropriate and straightforward policy be required. Larry (2011: 7) quoted by Narendrasmoro pointed out that policy is "the combination of basic decisions, commitments, and actions made by those who hold or influence government positions or authority.” Guess (2011: 7) noted in the following that policy is made by a legislative institution and administrative government. In practice, policy is a ruling system and standard that influences public interest and is formulated by a ruling institution i.e. parliament, legislative, and administrative-regulation institution. The policy can be made for implementation in the internal government institution or the external programs and services.

A straightforward policy significant to a wide-ranged society can be merely formulated by a competent leader and remain relevant with stakeholders. This is in accordance with Davis (1996) noting that competence is human characteristic that emerges from combination between knowledge and skill. The definition implies that not only does competence refer to combination or totalization of knowledge and skill but also multiplication of them. This will mathematically result as many times as they multiply in one's daily activity. Kenezevich (1984: 17) shared similar perspective that competence is a combination of skills to meet the organizational objectives. Both perspectives, thus emphasize competence as a combination of multiple skills i.e. knowledge, skill, leadership, intelligence, etc. one possesses to meet the organizational objectives.

The competence a leader of legislative or executive owns does not emerge abruptly in practice but has to be preceded with quality recruitment and selection processes. Mondy (1996) suggested that "Selection is the process of choosing from a group of applicants the individual best suited for a particular position”. Thus, a selection process is an initial stage that determines an organization to qualify required candidates with excellent and professional competence. Gatewod and Field (2002) claimed that a selection is a process to collect and evaluate individual's information qualified for the recruited candidate. The information and data derived from recruitment highly determines the selection process in which the candidate is classified into "accepted or denied”. Nawawi (2001: 169) stated that recruitment is a process undertaken to appoint quality workforce for major position/occupation in an organizational/company's environment. Whereas Cardoso Gomes (2003:13) defined recruitment as a process to seek, find and recruit applicants for employment in and by an organization. 
The perspectives abovementioned are in accordance with Yulliyanti's (2009) who investigated that a recruitment process brings a significant influence towards selection that will also enable the work performance. With reference to the study, Muhamad Aji (2012) investigated that a positive influence of recruitment and selection does exist on employees' work performance.

Based on the background described, hypothesis of the study is that a change in national condition is directly influenced positively by recruitment, selection, competence and policy.

\section{METHOD}

\section{Participants}

Participants or this study were sample of Indonesian people from 33 provinces who were selected on the following conditions: a) aged above 17 and or married, b) having resided in one city for minimally 2 (two) years, c) being active in a social organization and having graduated from High School (SMU), d) Not belonging to a member of political party, NGO, and government employee or other professions directly relating to object of study. Thus, 530 respondents of 25 provinces scattering amongst 50 regencies/cities - respectively divided into 25 districts - were selected by means of Stratified Proportional Multistage Random Sampling.

\section{Data Analysis}

A survey method was employed in this quantitative study to explore the relationship involving amongst recruitment (X1), selection (X2), competence (X3), policy (X4) and change (Y) variables. Data was collected by using 1-5 Likert scale. A validity test with Product Moment correlation and Alpha Cronbach reliability calculation were conducted prior to distributing the questionnaire.

It was necessary to perform a requirement analysis testing i.e. normality and linearity before hypothesis testing was conducted. Findings of normality test of data galat taksi using Kolmogorov-Sminorv Z. test show p-value for data galat taksiran of variables: Selection (X2) on Recruitment ((X1), Competence (X3) on Recruitment (X2), Policy (X1) on Recruitment (X1), Policy (X4) on Selection (X2), Policy (X4) on Competence (X3), and Change (Y) on Recruitment (X4) remain all above 0.05. It proves no difference between theoretical and empirical distribution so that all variables have normal distribution. Meanwhile, linear regression test was employed by means of Anova. Findings reveal that Ho is approved or there is a linear relationship between exogenous and endogenous variables shared.

The obtained data was analyzed by means of descriptive and inferential statistics. Descriptive analysis employed was to describe the central measurement and distribution of respective variables. A path analysis was used as an inferential analysis to test the research hypothesis.

\section{RESULTS AND DISCUSSION}

Findings reveal that based on the descriptive analysis, the variables on the change of national condition, policy, competence, selection and recruitment has not 
met society's expectation. The descriptive analysis of the variables is presented on Table 1.

It was necessary to perform a requirement analysis testing i.e. normality and linearity before hypothesis testing was conducted.

Findings of normality test of data galat taksi using Kolmogorov-Sminorv Z. test show p-value for data galat taksiran of variables: Selection (X2) on Recruitment ((X1), Competence (X3) on Recruitment (X2), Policy (X1) on Recruitment (X1), Policy (X4) on Selection (X2), Policy (X4) on Competence (X3), and Change (Y) on Recruitment (X4) remain all above 0.05. It proves no difference between theoretical and empirical distribution so that all variables have normal distribution.

Table 1. Summary of Data on Change, Recruitment, Selection, Competence and Policy

\begin{tabular}{lcccc}
\hline \multicolumn{1}{c}{ Variable } & Mean & $\begin{array}{c}\text { Deviation } \\
\text { Standard }\end{array}$ & Variant & Category \\
\hline Change & 87.28 & 24.19 & 584.92 & Less appropriate \\
Recruitment & 78.59 & 18.23 & 332.16 & Less appropriate \\
Selection & 100.31 & 25.59 & 654.861 & Less appropriate \\
Competence & 52.31 & 13.87 & 192.24 & Less appropriate \\
Policy & 59.14 & 16.04 & 257.21 & Less appropriate \\
\hline
\end{tabular}

Linear regression test was then employed by means of Anova Table procedure. Findings reveal that Ho is approved or there is a linear relationship between exogenous and endogenous variables shared.

Hypothesis testing was performed for each structure of hypothetical modeling that includes impact test of the following variables: Policy (X4) on Change (Y), Recruitment(X1) on Policy (X4), Selection (X2) on Policy (X4), Competence (X3) on Policy (X4), Recruitment (X1) on Competence (X3), Selection (X2) on Competence (X3), and Recruitment (X2) on Selection (X2). Findings of path coefficient test are described as follows:

Table 2. Summary of Hypothesis Testing $(\alpha=0,05)$

\begin{tabular}{|c|c|c|c|c|}
\hline $\begin{array}{l}\text { Path } \\
\text { coefficient }\end{array}$ & t-calculation & t-table & $\begin{array}{l}\text { Findings of } \\
\text { Analysis }\end{array}$ & Conclusion \\
\hline $\mathrm{p}_{4}=0,35$ & 8.60 & 1.65 & Ho denied & Significant \\
\hline $\mathrm{p}_{41}=0,19$ & 4.52 & 1.65 & Ho denied & Significant \\
\hline $\mathrm{p}_{42}=0,18$ & 4.20 & 1.65 & Ho denied & Significant \\
\hline $\mathrm{p}_{43}=0,33$ & 7.11 & 1.65 & Ho denied & Significant \\
\hline $\mathrm{p}_{31}=0,36$ & 10.03 & 1.65 & Ho denied & Significant \\
\hline$p_{32}=0,41$ & 11.53 & 1.65 & Ho denied & Significant \\
\hline $\mathrm{p}_{21}=0,29$ & 7.03 & 1.65 & Ho denied & Significant \\
\hline
\end{tabular}

The hypothesis testing is visualized in the causal empirical model below:

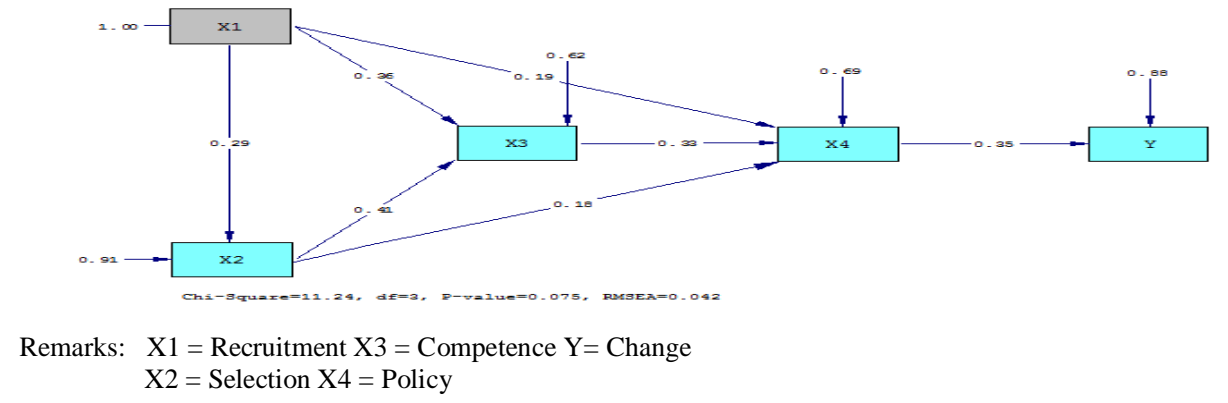

Figure 1. Causal Empirical Model 
The accuracy of this empirical model is analyzed by means of model fit testing using Chi-Square and RMSEA (Root Mean Square Error of Approximation).

Proposed hypothesis of Chi-Square test: Ho: empirical data identical with hypothetical model, if $\mathrm{p}$-value $\geq 0,05 ; \mathrm{H1}$ : empirical data different from hypothetical model, if p-value < 0,05. Proposed hypothesis of RMSEA: Ho: empirical data identical with hypothetical model, if p-value < 0.05; H1: empirical data different from hypothetical model, if p-value $\geq 0.05$.

The fitness testing between hypothetical model and model fit data is as follows:

Table 3. Summary of Model Testing Result

\begin{tabular}{llll}
\hline Testing Statistics & p-value & Criteria & Conclusion \\
\hline Chi-Square & 0.075 & 0.05 & Model fit \\
RMSEA & 0.042 & 0.05 & Model fit \\
\hline
\end{tabular}

The result shows that Chi-Square and RMSEA have a model fit, in other words, the hypothetic model fits the data.

\section{DISCUSSION}

\section{Positive Direct Influence of Policy towards Change}

Findings reveal that Policy has a direct positive influence towards change. As far as we have perceived that a change is an outcome of policy. In the scope of organization, an organized community or a governed nation is to take place when policy exists. Yet, who does issue the policy? In a national political situation, particularly during transition era of democratization of the country, it is recommended that a political party representing peoples aspiration exist with a view to issuing a policy (output) for the sake of the people. The policy is set out by the leaders of executives and legislatives who paly role as a cadre of the party functioning as officials in public administration or government, carrying out three principles (Wiranto, 2009: 8) namely: 1) mandate principle - receiving mandate from the people, 2) representation principle - representing people's political rights, and 3) accountability principle - bearing responsibility for the people. Therefore, not only will the formulated policy focus on political interest with its participants, but also all people in the country primarily. Policy intended for public interest is one that allows sustainable growth for the people. The central or regional government officials are called functionary in public administration who governs the bureaucracy. The government performs a serious duty to formulate principles of good governance into a universal government system. Thus, officials competent in respective field is highly required.

This finding is in accordance with the locus of leadership theory claiming that leadership will meet its effectiveness when the three factors i.e. character of the people, condition of the nation and character of the leaders are to coincide on the range. When this happens, a leader will have succeeded in grasping people's aspiration, understanding people's expectation and perceiving current and future condition. Based on this, a leader should design a policy enabling a change expected by the people to occur. Descriptive analysis shows a very low score on Policy and Change variables from the respondents. It signifies that the change directly affecting people's life has not come in realization though government has claimed that a good 
change in national condition results from high rates of macro economy development. Thus, should drawbacks be found in terms of the gap, a correction in policy execution is necessarily performed.

Kasali (2006) noted that a change requires a leader with strong will and competence. In fact, many leaders have been trapped into a comfort zone with their security blanket. Comfort Zone refers to one where conspiracy and collaboration amongst the executives, legislatives, upholders and businessmen are committed to bargaining power. With the authority they have, they are trying to take advantage, seek comfort zone and establish their private security. Moreover, the NGO participants or activists who formerly hold on to their political idealism might become powerless and effortless when entering the Comfort Zone. They are indulged by abundant luxury, nauseated by social status, and ruled by the power of material being. This group of leaders actually carry with them enormous fear of the change for the change absolutely enables them to lose what they have had in hand. To survive in the comfort zone, they collectively maintain multiple positions in a political organization and build their political clan. Misdirected political interest they practice has allowed their position to be an instrument to obtain resources of the party.

There have been numerous corruption cases revealed and investigated by Indonesia's Corruption Eradication Commission (CEC), however, failed to be executed. This zone is described as if it had an octopus tentacles which indulges those who disrupt the comfort. Another practice also occurs in the local government election to appoint Head of the district upon which is bestowed to the child or wife having maintained it for two-period in sequence. Some even maintain their power by lowering themselves for the position of the Vice Head of the district.

The role of leaders in the Republic of Indonesia - the four-ranked biggest population in the world - is heavier than that of a director in a company. It is required that selected figure be taken into account to be the leader, not only doing things right, or doing the right thing but also having power as crackers to break the people out of its status quo and enter a new promising zone in the future.

\section{Positive Direct Influence of Selection towards Policy}

Research findings reveal that the selection has a positive direct influence of towards policy. The differences between the selection carried out in political and non-political organizations will be explained further. In a business organization and other non-political organizations, the selection is a part of recruitment. It also applies to a political organization in which the recruitment undergoes three levels. Firstly, it is carried out through intra-party scope where people compete for power and position within the party e.g. young cadres will have early promotion to substitute the elderly due to the chance. Secondly, it is carried out through inter-party scope where cadres of inter-political parties compete against for political power through general election. This situation allows intermittent changes which are initiated and promoted by each political party to level up one's position e.g. the lost part in the previous election is still able to reform and select its candidates for the next general election. Thirdly, it is carried out through a political system in which parties are selected by development of social, technology, and culture in order to survive, or reformed by the country for the sake of long-term interests. 
This study focused on the second level in which cadres of political parties compete against one another for political power from where policies are stemmed by the government officials. These policies are series of enforced decisions as referred to Eston's "policy is a process of allocating values to society forcibly implemented by the authority in this sense, government.” It can be concluded that inappropriate policies may burden high risk not only to individual but also society. The selection of future leader in government will therefore significantly influence future policies set out.

Previous findings reveal that the evaluation of the selection process through direct general election has remained low. This greatly concerns us because the unqualified selection process may allow unqualified policies to formulate. Public opinions of Indonesia regard that the current general election held has committed to irregularities and involves serious problems that highly impact legitimacy and quality leaders. The irregularities taking place are as follows: inaccurate electoral voters list, campaign violations, money politics, in-transparent counting process, and other problems occurring in the general and local government elections.

The selection by means of direct general election through one man one vote has already representing the principles of democracy procedurally and substantially. However, disorientations in its practice have almost been investigated so that it might desecrate democracy. The general election will function best to appoint the real leader provided that its implementation runs without the absence of fundamental improvement.

\section{Positive Direct Influence of Competition towards Policy}

Research findings reveal that the competition has a positive direct influence towards policy. A future successful leader must have credibility i.e. personal excellence, good values, and competence to gain trust and commitment that used to make a policy. Leader's competence is one of the most important factors a leader should have for making policy-based decisions. If competence is a collection of abilities embedded in individual to perform certain tasks, a policy is the actualization of it into decision to meet particular objective. It can be perceived that quality policies refer to leaders with excellent competence and vice versa.

Previous findings pointed out that the low score on government officials' competence and policy collected from respondents show people's dissatisfaction with their performance. It has not come to a surprise that it reflects how reality happens. People can explicitly see a number of officials in executives and legislatives committed power abuse and corruption. This fact is definitely a serious problem to address on how low competence and weak policies are implemented by the government.

The change in officials' behavior that formerly functions as a leader having great concern about people has led to a power which put themselves as little kings. This contributes to absurd competence they own.

\section{Positive Direct Influence of Recruitment toward Competence}

Research findings reveal that recruitment has a positive direct influence towards competence as claimed by Richard (2005) that recruitment is a process to seek competence that reflects the importance of human factor aiming at organizational success. One of human factors contributing to organizational success 
is competent people to fill in the right position. It is supported by Taylor (2008) who noted that competence is a principle characteristic required by people to result superior job performance. It can be concluded that there is a casual relationship between recruitment and competence. Competent leaders or officials may come to life if the recruitment process succeeds to select of official candidates that meet expected talent and potential.

\section{Positive Direct Influence of Selection toward Competence}

Research findings reveal that the selection has a positive direct influence towards competence. Kasali (2011) supported that in terms of human resources, especially in a government organization, a leader of change with crackers competence will not function as a sole manager since he is more than just the leader. This leader is eager to make a huge change, break the past, and create a new thing for better future of the people, having hopes for the ideals.

Problem currently encountered is the low respondents' appreciation on the selection process of executives and legislatives by the General Election Commission. There has been lots of current general election has a lot of irregularities and violations. All components involved in general election have contribution to serious mistake, irregularities, and violations. First, it starts from the organizer who earns little salary. This inconvenience can drive them to vote transaction in addition to intransparent vote counting system that is likely to create suspicion. Second, it grows up to the respondents in mediocre condition who seemingly become highly vulnerable with money politics. The witnesses that should be appointed from militant cadres remain otherwise. Indeed, they have become commodities of interest. The society has already set a market price for the witnesses at all level of general election processes. Moreover, it is a public secret that the voters have already been a transactional politics. Quality of candidates is no longer a major consideration; yet, the more one gives, the more one wins the most votes. Third, it ends up in the candidate who truly happens to be unable to meet the basic competence as a leader of executives and legislatives. It appears a paradox that candidates who have good competence lack political resources and vice versa.

It can be concluded that the improper selection process will produce a leader with excellent competence.

\section{Positive Direct Influence of Recruitment towards Selection}

Research findings reveal that recruitment has a positive direct influence towards selection. It means that recruitment is directly associated with human resources planning and selection because it is in this process that the first contact between the organization and the cadre candidate take places inclusively building cadres' interest in their job description. The situation may create a variety of activities that provide an opportunity for organization to carry out observation and assessment of candidate. Recruitment is also closely related to the whole human resources planning for it serves as an upstream process of human resources provision that will determine following processes including selection. The failure of recruitment may lead to failure of creating a leader of change as well. 


\section{CONCLUSION}

Based on empirical findings and discussion of the research, it can be concluded that a change in national condition will not occur if the whole chain in relation to policy-making by a leader of change has many weaknesses and mistakes. It can thoroughly be presented as follows:

First, policy has a positive direct influence towards change. The policy made by the executives and legislatives determines the existence of the change in national condition. There have not yet been influenced policies created by the leaders to make a change, getting rid of status quo. This results from a number of executives who pay less focus on their public occupation. They must perform their public duties and occupation, on one side, and manage their political party on the other side.

Second, recruitment has a positive direct influence towards competence. A change in quality of political party cadre recruitment projected as candidates of executives or legislatives would allow a change in quality of policies the central and local government set out.

Third, selection has a positive direct influence towards policy. A change in quality of executives or legislatives selection through general and local government election would allow a change in quality of policy the selected leader sets out.

Fourth, competence has a positive direct influence towards policy. The competence the executives or legislatives derive from general election of practicing quite lots of irregularities has distorted the quality of policy the leader set out.

Fifth, Recruitment has positive direct influence towards competence. Recruitment of potential leaders conducted by political parties is still affected by disorientation of what should be done, as stipulated in the law concerning political party responsibility. In consequence, leaders' competence has been systematically degraded.

Sixth, selection has a positive direct influence towards competence. A change in selection process conducted through General Election will result a change in the competence elected leaders own.

Seventh, recruitment has a positive direct influence towards selection. A change in the recruitment process performed by political parties will result a change in selection process conducted in national and local general election.

Recommendation of the study emphasizes that improvement in the quality of recruitment by political parties, in the selection process by General Election Commission and in the competence and policy by the leaders to ensure a change in national condition is required with a view to realizing what Indonesian people have aspired the most.

\section{REFERENCES}

Aulia, Rafika. (2013). UNDP: Indeks Pembangunan Manusia Indonesia Naik. Majalah Tempo. Online: www.tempo.co

Beer, Michael. (2002). Breaking the Code of Change. Boston: President and Fellow of Harvard College. 
Davis, Keith and Newstrom, John W. (1996). Human Behavior at Work, Organization Behavior. 8th edition. Singapura: Mc. Graw Hill Book Company.

Gomes, Faustino Cardoso. (2003). Manajemen Sumber Daya Manusia. Penerbit Andi, Yogyakarta.

Guess, George M. and Paul G. Farnham. (2011). Case in Public Policy Analysis. Washington: Georgetown University Press.

Kahar, Irawaty A. (2008). Konsep Kepemimpinan dalam Perubahan Organisasi (Organizational Change) pada Perpustakaan Perguruan Tinggi. Pustaka: Jurnal Studi Perpustakaan dan Informasi, Program Studi Ilmu Perpustakaan, Universitas Sumatera Utara, Vol.4, No.1, Juni 2008, 22.

Kasali, Rhenald. (2006). Change. Jakarta: PT. Gramedia Pustaka Umum.

Kasali, Rhenald. (2011). Cracking Zone. Jakarta: PT. Gramedia Pustaka Utama.

Kenezevich, Stephen J. (1984). Administration of Public Education. New York: Harper Collins Publishers

Mondy, Wayne, and Robert M. Noe. (1996). Human Resources Management. New Jersey: Prentice Hall Inc.

Narendrasmoro, Yudithstiro, Arizona Foundation for Legal Services and Education (2007) http://www.azflse.org/pcitizen/publicpolicy.cfm [access date: 22 February 2013].

Nawawi, Hadari. (2001). Manajemen Sumber Daya Manusia. Yogyakarta: Penerbit Gadjah Mada University Press.

Purhantara, Wahyu. (2009). Organizational Development Based Change Management. Jurnal Ekonomi \& Pendidikan, STIE Mitra Indonesia, Volume 6, Nomor 2, November 2009, 155.

Richard, Daff L. (2005). The Leadership Experience. Canada: Thomson.

Taylor, Ian. (2008). Measuring Competency for Recruitment and Development. Terjemahan Paulina Ruri, Jakarta: PPM.

Yulliyanti, Ellyta. (2009). Analisis Proses Rekruitmen dan Seleksi pada Kinerja Pegawai, Bisnis \& Birokrasi. Jurnal Ilmu Administrasi dan Organisasi, September-Desember 2009, halaman 131-139. 